\title{
Status of the Atlantic walrus Odobenus rosmarus rosmarus in the Svalbard area
}

\section{ERIK W. BORN}

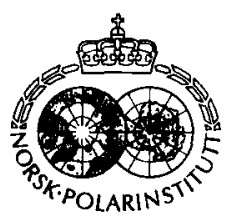

Born, Erik W. 1984: Status of the Atlantic walrus Odobenus rosmarus rosmarus in the Svalbard area. Polar Research 2 n.s., 27-45.

Observations of walrus in the Svalbard area in the period 1954-1982 indicate an increase since 1970 in the numbers summering in this area. The numbers of walrus observed show annual fluctuations. With the exception of 1973, when at least 300 animals were observed on one occasion at Kvitøya, the observations indicate a summering stock of about 100 animals. In 1982, when most walrus habitats in Svalbard were surveyed, observations of 248-274 animals were recorded. These observations were estimated to represent $82-85$ individuals.

During summer, walrus are most frequently observed at Tusenøyane, in Murchisonfjorden and along adjacent coasts, along the northern coast of Nordaustlandet, at Kvitøya, and at Moffen. Apparently, the walrus re-established the use of Moffen as a summer haul-out site about the beginning of the 1970 s.

An apparent under-representation of observations of females with dependent calves in Svalbard indicates that the area is mainly used as a summering area by males and that Svalbard is in the process of being repopulated by an extension of a population centred elsewhere. It is suggested that the walrus summering in Svalbard belong to a population with its main distribution in the Frans Josef Land archipelago, but at least some may be derived from a walrus population(s) occurring at Novaja Zemlja and in the Kara Sea.

Erik W. Born, Greenland Fisheries and Environment Research Institute, Tagensvej 135, 2200 Copenhagen N. Denmark; November 1983 (revised April 1984).

\section{Introduction}

The Atlantic walrus Odobenus rosmarus rosmarus occurred abundantly in Svalbard when the English whalers took the first catch at Bjørnøya (Bear Island or Cherrie Island) in 1604 (Lønø 1970). However, reckless hunting, first by English, Dutch and Danish whalers and later by Soviet and Norwegian sealers, depleted the walrus in the Svalbard area to the verge of extinction (Lønø 1970). The walrus in Svalbard was given complete protection in 1952 (Anonymous 1966).

Løn $\emptyset$ (1970) has summarized the historical walrus catch in the Svalbard area, and recent trends in the development of the population have been described by others (Norderhaug 1967; Øritsland 1973; Larsen \& Norderhaug 1974). In this study I review the observations of walrus since 1954 and estimate its present status in Svalbard.

\section{Materials and methods}

Observations of walrus presented in this review were obtained from field parties working in Svalbard in the period 1954 to 1982 and from surveys of marine mammals conducted in 1980, 1981, and 1982.

Wildlife-observation recording forms. - Observations of walrus in the Svalbard area have been reported by various field parties and by weather station personnel. Since 1963, the Norwegian Polar Research Institute has supplied expeditions working in Svalbard with wildlife-observation recording forms. The data presented in this paper are derived from the completed forms which are kept at the Institute. Reference is made to previous papers based on the same source. Additional walrus observations published in other sources have been included.

Surveys, 1980. - During the cruise of the Swedish ice-breaker 'Ymer' in the Svalbard area in July-September 1980 (Fig. 1), continuous observations of marine mammals were made from the top-deck, $24 \mathrm{~m}$ above sea level. In this study, which was designed as a line-transect survey, $95 \%$ of all marine mammals observed were detected within a distance of $3000 \mathrm{~m}$ to each side of the ship's course (T. Larsen, pers. comm.).

A walrus survey was conducted from 'Ymer' 


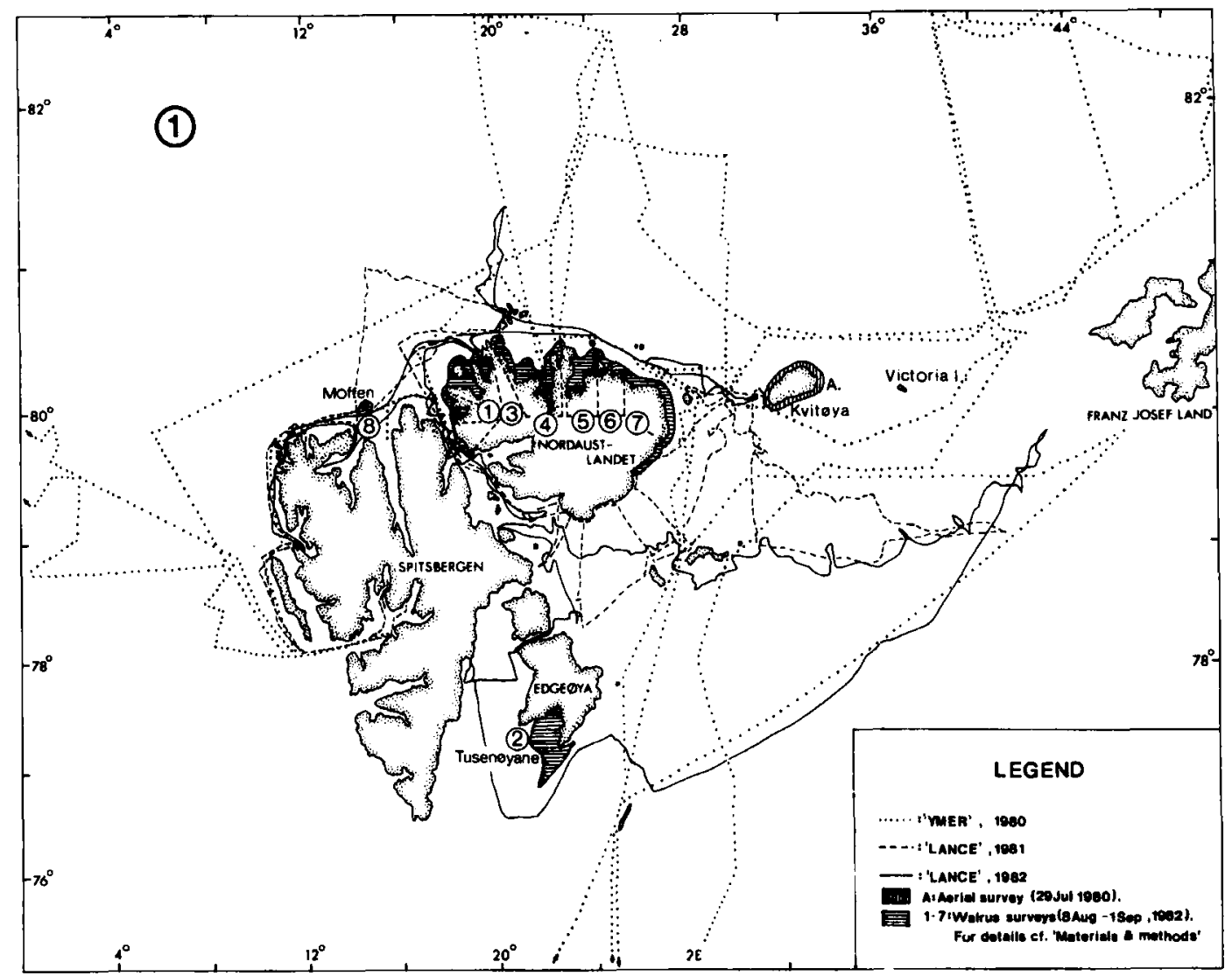

Fig. 1. The cruise tracks of the ice-breaker 'Ymer' (1980) and 'Lance' (1981 and 1982). Areas where walrus surveys were conducted are hatched.

from a Bell 206 Jet Ranger helicopter along the coast of Kvitøya on 29 July 1980 (Survey A, Fig. 1. Altitude about $150 \mathrm{~m}$. Air-speed: 150$160 \mathrm{~km} / \mathrm{h}$ ).

Surveys, 1981. - A line-transect study was conducted in the period 28 June to 2 September 1981 during the cruise of the Norwegian research vessel 'Lance' in the Svalbard area (Fig. 1). Walrus were not observed during this cruise, where observations of marine mammals were made from $12 \mathrm{~m}$ above sea level.

Surveys, 1982. - In the period 1 August to 4 September 1982, 'Lance' made another line-transect study in the Svalbard area (Fig. 1). Survey efforts were concentrated on areas known to be walrus habitats, so that these areas were surveyed specifically, either from boat or helicopter (Bell
206 Jet Ranger. Altitude: 100-150 m. Air-speed: about $150 \mathrm{~km} / \mathrm{h}$ ).

On 8 August the coastal areas from Langgrunnodden south to Sparreneset, including Murchisonfjorden, were surveyed by two boat teams (Survey No. 1, Fig. 1). Tusenøyane were surveyed by helicopter on 18 August (Survey No. 2, Fig. 1). On 28 August a helicopter survey was conducted along the coast from Brageneset north to Svartneset, including the coast of Lagøya (Survey No. 3, Fig. 1). Three aerial surveys were conducted along the northern coasts of Nordaustlandet. On 29 August the coastal areas of Nordenskiöldbukta, including Sabineøya and Scoresbyøya, were surveyed from the northern point of Laponiahalvøya eastwards to Kapp Platen (Survey No. 4, Fig. 1). On the same date, Duvefjorden and the coastal areas east of Albertinibukta were surveyed (Survey No. 5, Fig. 1). 
On a subsequent flight on 29 August the coast from Bergstrømodden east to Běhounekodden was surveyed (Survey No. 6, Fig. 1). On 30 August, observations were made from a helicopter along the eastern coast of Nordaustlandet (Survey No. 7, Fig. 1). Two boats surveyed the southern and eastern coasts of Moffen Island on 1 September. Strong winds prevented the circumnavigation of the island, but the western coastal areas were studied with binoculars from land.

The author participated in all surveys except No. 7, and attempted to determine the tusk length and sex of each animal encountered. Ages were estimated from comparison of observed tusk length with tusk length/age data for walrus in the eastern Canadian Arctic (Mansfield 1958) and northern Greenland (Born, unpubl. data).

Because some of the observations of walrus recorded in one year may have represented multiple sightings of the same animals, I have tried to extract from the data the minimum number of individuals observed annually. This was done by comparing information on the date of observation, observations of herds versus single animals, data on sex, body size, and tusk length.

\section{Results}

\section{Seasonal and regional distribution}

In the period 1954 to 1982 , twelve observations of walrus from late winter (February-May) were recorded in the Svalbard area (Fig. 2). These observations, representing 18 animals, were all made along the southern, western and northwestern parts of the archipelago, where ice conditions are usually light during winter (Vinje 1975, 1980).

At the time of ice break-up (June-July), five

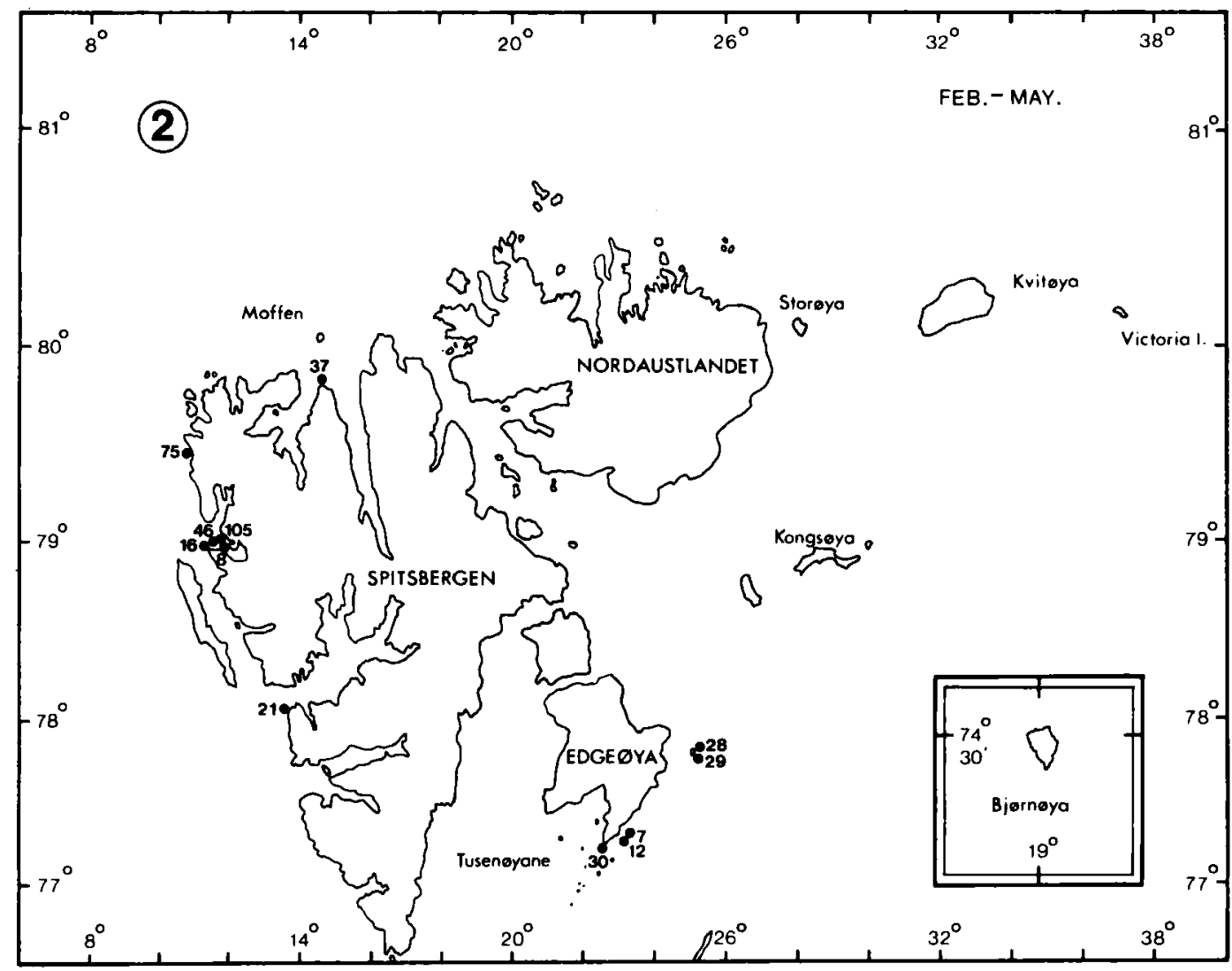

Fig. 2. Distribution of walrus observations in late winter and early spring in the Svalbard area. Numbers refer to number of observations (Appendix) not number of animals observed. 


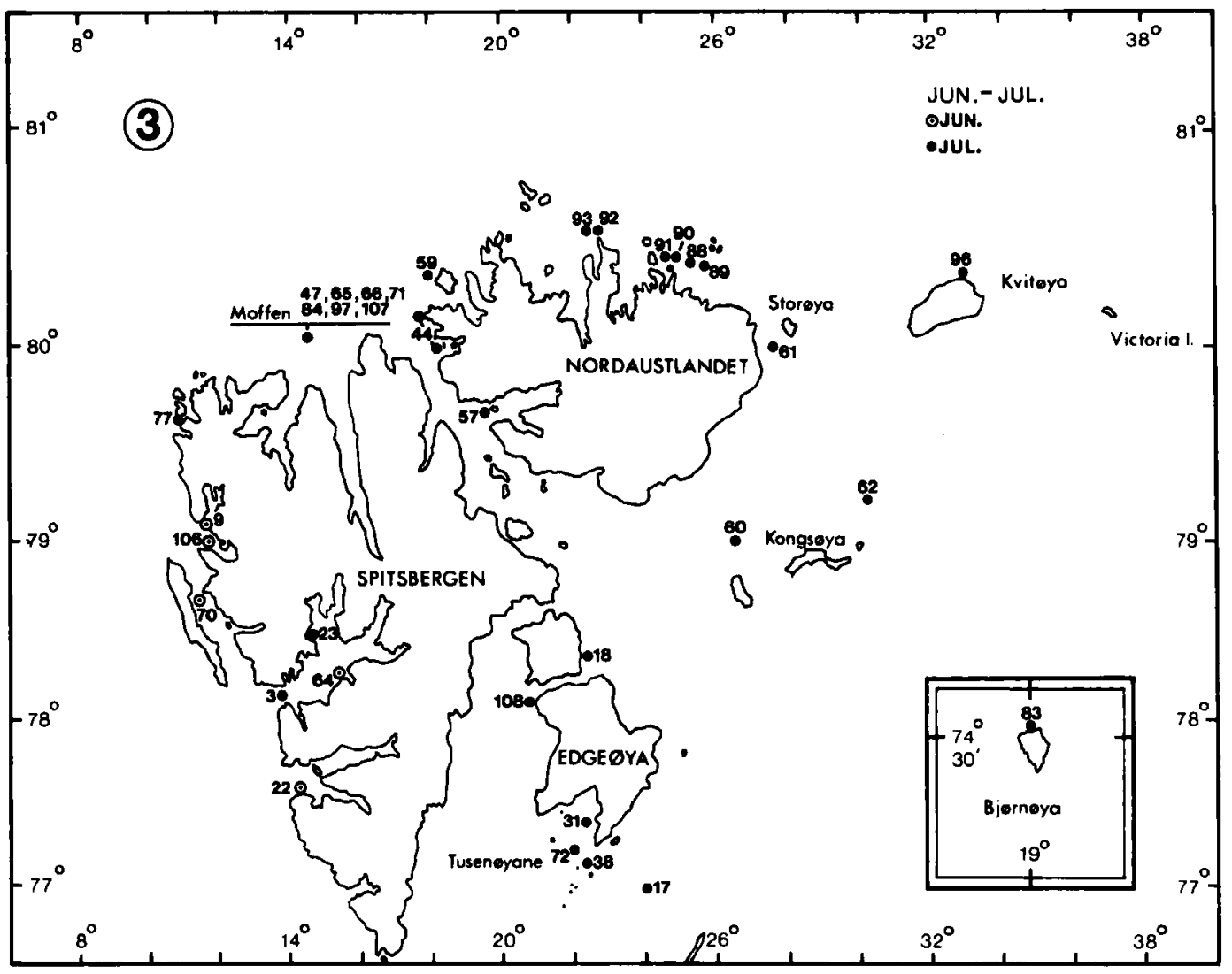

Fig. 3. Distribution of walrus observations at ice break-up in the Svalbard area.

observations of walrus were recorded in June and 29 in July (Fig. 3). All observations made in June were from the western part of Spitsbergen, while the majority of the July observations were made in southeastern and northeastern parts of the Svalbard archipelago.

The earliest observation of walrus at Moffen Island is 11 July (Appendix, obs. No. 107). Observations indicate that they arrive at Moffen during the second half of July (Appendix, obs. Nos. 47, 65, 66, 71, 84, 97).

Noteworthy is the observation of an adult walrus on 20 July 1979 on Bjørnøya (Appendix, obs. No. 83). This is the first recorded observation of walrus at this island since 16 February 1866 (Lønø 1970).

In the open-water summer period (AugustSeptember), there is virtually no ice in the western parts of Svalbard, and in the northeastern parts the ice conditions are usually light (Vinje 1975,
1980). The majority of walrus observations were made in August ( $n: 68$ ), while only two observations from September were recorded. This difference between August and September in the number of observations may well reflect the fact that in August research activity is usually at a maximum in Svalbard. The spatial distribution of observations in this period (Fig. 4) is similar to that observed in July (Fig. 3). Most observations were made at Moffen, in Murchisonfjorden and along adjacent coasts, at Tusenøyane, and at Kvitøya.

Only five observations of walrus were recorded from the time of freeze-up in the autumn (October-November). Two were made in October and three in November. With the exception of one observation in Ny-Ålesund on the west coast of Spitsbergen, the other four were made at Tusenøyane in south Svalbard. The observations represent 15 individuals (Fig. 5). 


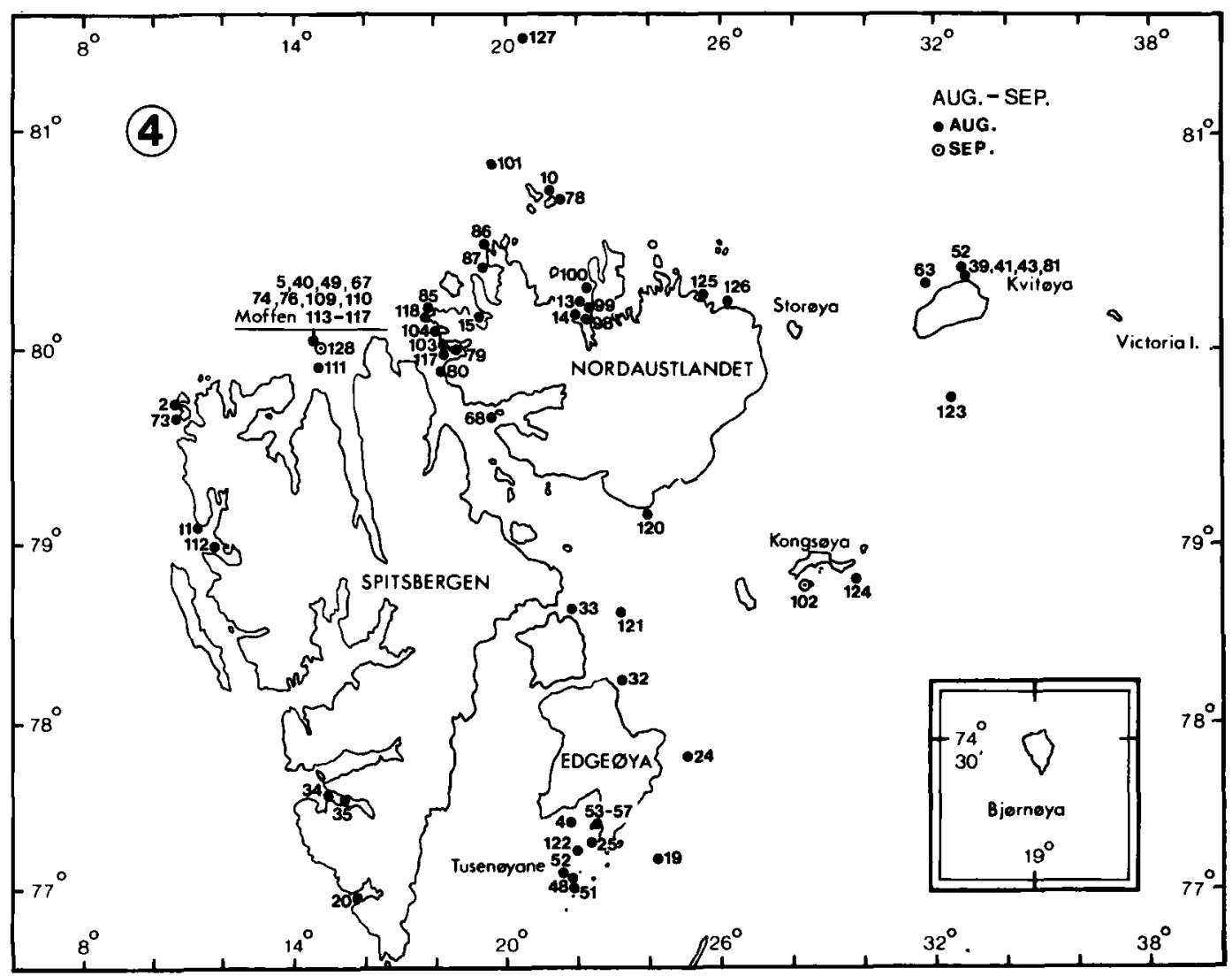

Fig. 4. Distribution of walrus observations in the open-water period in the Svalbard area.

\section{Numbers observed}

The total number of walrus observed per year is given in Table 1. There has been a slow increase in the total number of walrus observed in Svalbard from 1954 until 1969 (Table 1). From 1970 the annual number of observations has fluctuated with an average of about 90 animals per year. Although the total number of observers reporting to the Norwegian Polar Research Institute has doubled during the 1970 s compared with the 1960 s (Table 1, column A), the number of observers (Table 1, columns B and C) has remained low and somewhat fluctuating throughout the 1970s. This indicates that the increase in number of walrus observed is not a direct effect of increased observation efforts.

The total minimum number of walrus observed annually was low during the 1960 s showing no apparent increase. In the 1970 s and the first two years of the 1980s the average minimum numbers observed were about 30 animals per year except for a remarkable observation on 10 August 1973 of 300 walrus near Kvitøya (Benjaminsen et al. 1973). The increase in number of walrus throughout the 1970 s is due mainly to an increase in numbers observed at a few localities (Kvitøya, Tusenøyane, Murchisonfjorden, and Moffen). This development is particularly pronounced at Moffen (Table 1).

The most consistent data on the total number of walrus in the Svalbard area were obtained in 1982 when known walrus habitats were systematically surveyed. During the cruise of 'Lance', a total of 57 walrus were observed, representing a minimum of 44 animals. Observations of walrus were made by other field-parties in July-August (Appendix). On 11 August, 50-60 walrus were observed at Moffen. Because of the variation of the dates of observation, however, multiple sightings of certain individuals cannot be ruled out. 


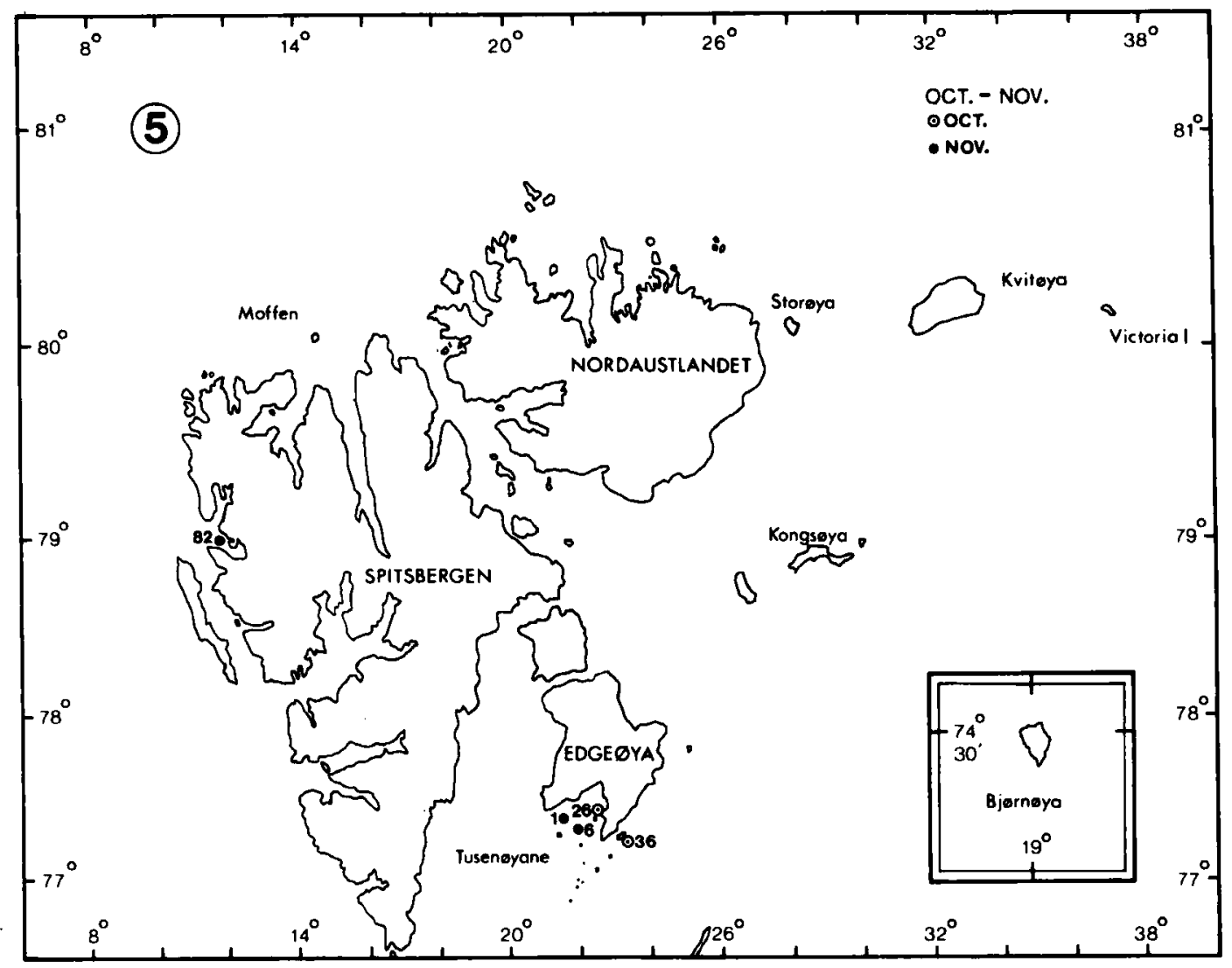

Fig. 5. Distribution of walrus observations in the period of formation of new ice in the Svalbard area.

The 1982 observations indicate that a minimum of 82-85 walrus summered in Svalbard (Table 1). This, however, may be an underestimate since the Kvitøya and Storøya areas were not surveyed entirely.

\section{Age and sex composition of the observations}

In the period 1954 to 1982 observations of a total number of 1155-1234 walrus were reported in Svalbard. The number varies because some observations of herds were given in approximate numbers. In about $64 \%$ of the observations, neither sex nor age class were reported. About $32-36 \%$ of the animals were classified as adults; of these, $4.2-4.5 \%$ were further identified as adult males and $2.7-2.9 \%$ as adult females. Subadults or young were reported in $1.6-1.7 \%$ of all observations and in $6.8 \%$ of the cases where the ageclass was given specifically. Only four of these young animals were classified as young of the year based on the lack of externally visible tusks. An exception to this underrepresentation of young is the observation on 10 August 1973 when relatively many young were observed among at least 300 walrus near Kvitøya (Benjaminsen et al. 1973, Appendix, obs. No. 52). The exact number of young is not stated in Benjaminsen et al. (1973), nor whether these young were newborn or older calves.

Of 50 walrus observed during the cruise of 'Lance' in 1982 (Table 2), 82\% (41 animals) were adults, estimated from tusk length to be more than eight years old. Nine animals $(18 \%)$ were subadults (seven years or less); one of these was a calf about two years old in a herd of adult females. Of 31 animals where I was able to determine the sex, 27 were identified as males $(87 \%)$ and four as females $(13 \%)$. In seven animals I was unable to determine either sex or age. 
Table 1. Observations of walrus in Svalbard 1954-1982.

\begin{tabular}{|c|c|c|c|c|c|c|c|}
\hline Year & \multicolumn{3}{|c|}{ No. of Informants } & \multicolumn{2}{|c|}{$\begin{array}{l}\text { Total no. of walruses } \\
\text { observed. }\end{array}$} & \multicolumn{2}{|c|}{$\begin{array}{l}\text { Estimated minimum } \\
\text { of total no. of } \\
\text { individuals } \\
\text { Entire } \\
\text { Svalbard } \\
\text { (Moffen } \\
\text { incl.) Moffen }\end{array}$} \\
\hline 1954 & - & - & - & $(10)$ & - & (10) & - \\
\hline $\begin{array}{l}1957 / 58 \\
-\end{array}$ & - & - & - & (4) & 一 & (4) & \\
\hline $\begin{array}{l}1960 \\
-\end{array}$ & 一 & - & 1 & 1 & - & 1 & - \\
\hline 1963 & $(-)$ & 1 & 1 & 2 & - & 2 & - \\
\hline 1964 & $(-)$ & 4 & 4 & 5 & 1 & 3 & 1 \\
\hline 1965 & 23 & 4 & 5 & 5 & - & 2 & - \\
\hline 1966 & 11 & 4 & 5 & 6 & - & 2 & - \\
\hline 1967 & 13 & 5 & 5 & 7 & - & 4 & - \\
\hline 1968 & 8 & 6 & 7 & 7 & - & 2 & - \\
\hline 1969 & 12 & 10 & 11 & 13 & - & 6 & - \\
\hline 1970 & 12 & 2 & 4 & $101-116$ & 1 & 51 & 1 \\
\hline 1971 & 18 & 2 & 4 & (3) & - & (2) & - \\
\hline 1972 & 10 & 2 & 4 & 38 & - & 9 & - \\
\hline 1973 & 19 & 5 & 12 & $(412)$ & 51 & $(300)$ & 40 \\
\hline 1974 & 20 & 4 & 6 & $118-128$ & $101-111$ & 41 & 41 \\
\hline 1975 & 24 & 2 & 5 & 73 & 66 & 58 & 53 \\
\hline 1976 & 22 & 3 & 3 & 14 & 6 & 6 & 6 \\
\hline 1977 & 21 & 2 & 2 & $18-19$ & $12-13$ & $12-13$ & $12-13$ \\
\hline 1978 & 23 & 5 & 6 & 48 minimum & 27 & 27 & 27 \\
\hline 1979 & - & - & 5 & 15 & 10 & 10 & 10 \\
\hline 1980 & - & - & 4 & 51 & 10 & 38 & 10 \\
\hline 1981 & - & - & 3 & (26) & - & (22) & - \\
\hline 1982 & - & - & 10 & $248-274$ & $(135-155)$ & $82-85$ & $50-60$ \\
\hline
\end{tabular}

A: total number of informants reporting observations of wildlife in Svalbard (Norsk Polarinstitutt Årbok 19651978).

B: Numbers among $A$ reporting walrus observations.

C: $B$ plus other sources.

Estimated minimum of total number of individuals was determined on basis of comparison of dates of observations and information such as sex and tusk length.

\section{Discussion}

The number of walrus in the Svalbard area before they were protected by law in 1952 is unknown and the possibility that there was a small wintering or sedentary stock cannot be ruled out. However, the few observations up to the summer of 1970 indicate that only stragglers frequented the archipelago in the period 1954-1970. For example, Tollén (1960) observed only four walrus in the period August 1957-July 1958 in the Murchisonfjorden area, in spite of the fact that this is a suitable walrus feeding area and haul-out site and that the area had open water in the winter of 1957-58.

Historically the walrus has wintered at
Bjørnøya and in the southern and western parts of Svalbard (Lønø 1970). The few recent observations of wintering walrus are also from these areas, where ice conditions are often light at this time. Taking into account that the ice conditions are often favourable and that these areas are walrus feeding grounds, the dearth of recent observations indicates that the southern and western parts of Svalbard are no longer important wintering grounds.

According to Lønø (1970) there was a sedentary walrus stock at Bjørnøya and along the southwestern part of Spitsbergen during the first centuries of whaling. Following the extermination of the stock in these areas the walrus hunt was 


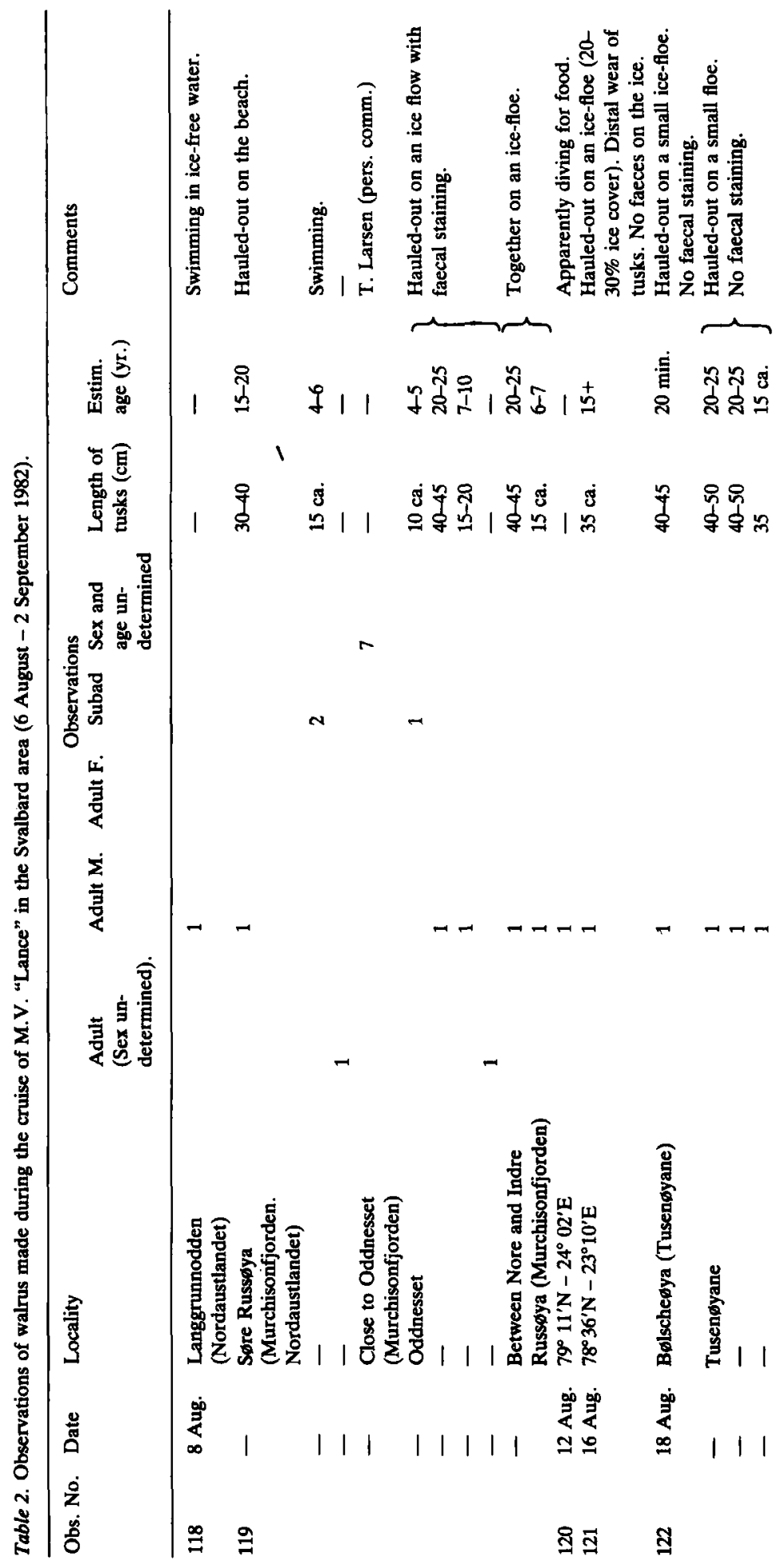



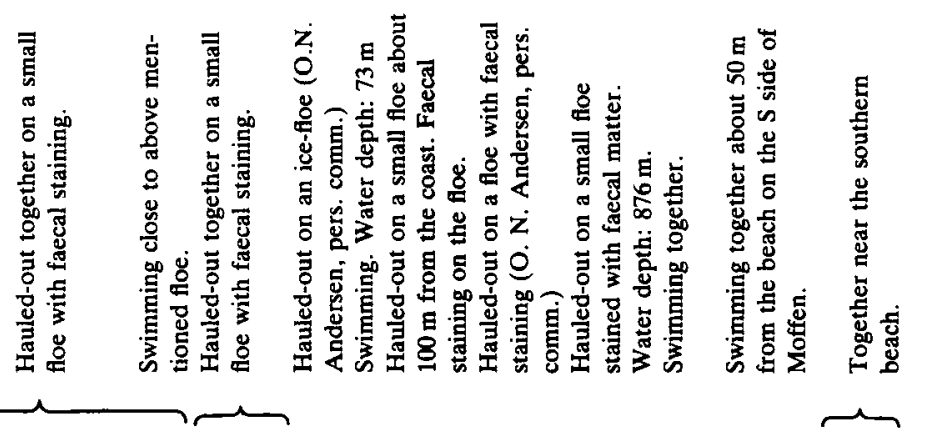

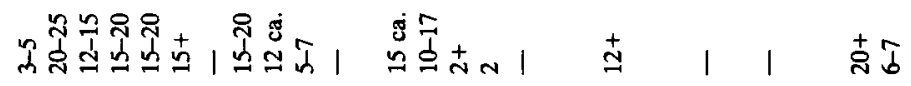

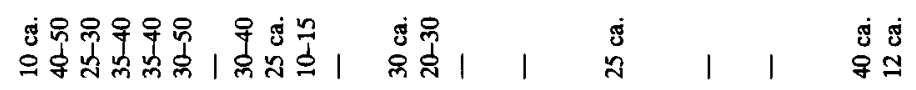

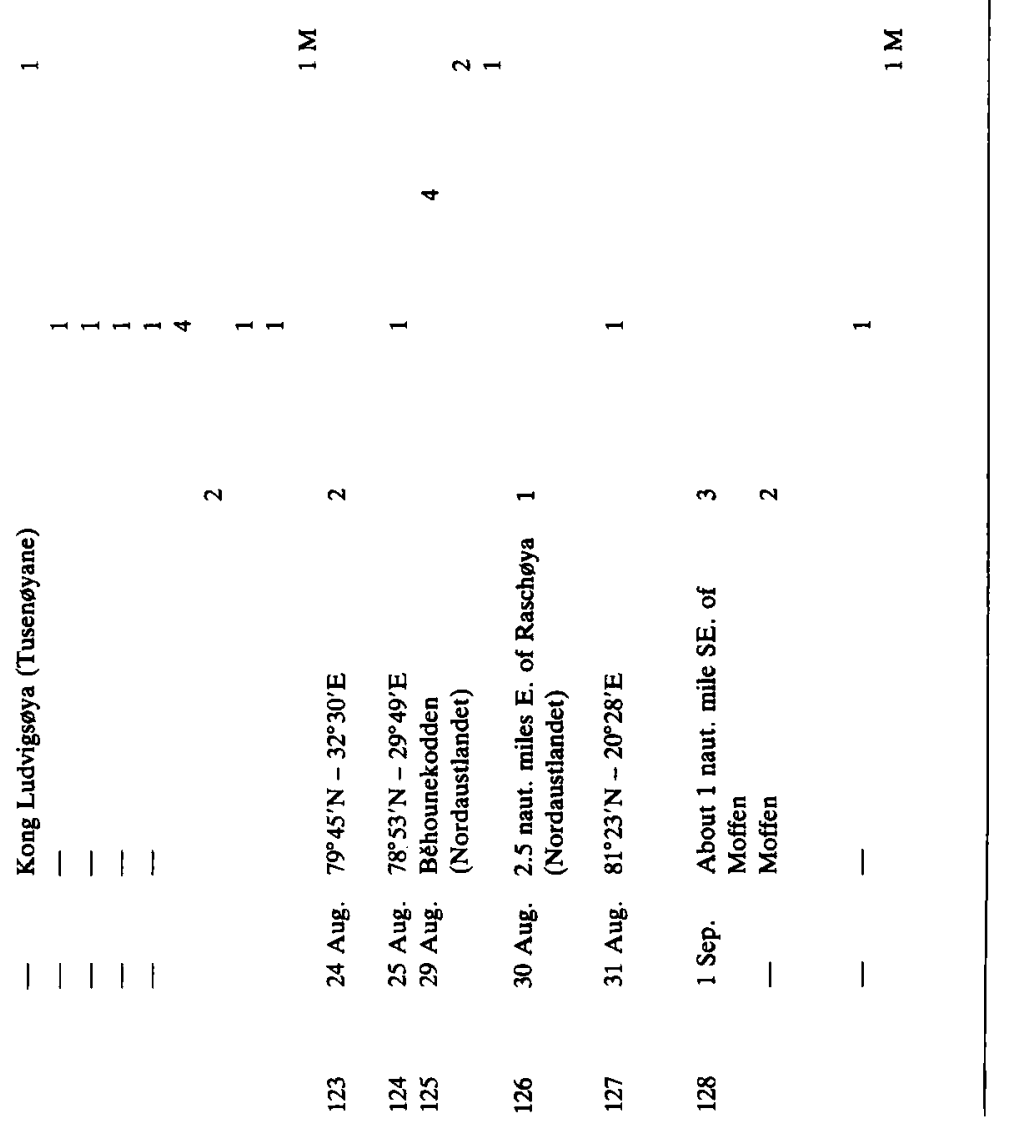


commenced in the northeastern part of Svalbard in 1863. As an indication of the presence of a more or less local walrus stock in these areas, Lønø (1970) points to the fact that the west coast of Svalbard was not replenished by walrus from the north and northeast 'where there was a stock of several thousand walrus'. A possibility exists that walrus may winter along the northern coast of Nordaustlandet, an area which is characterized by the presence of recurrent polynyas, according to Vinje (pers. comm.). However, in winters when these polynyas freeze up, the walrus are forced to winter elsewhere as for example in the southern and western parts of Svalbard. As far as I know, such a shift in occurrence of walrus has never been reported in Svalbard. Lamont (1876 fide Allen 1880) was of the opinion that the walrus in Svalbard reacted to the hunt by retreating into more remote and inaccessible areas. It is thus more likely that the walrus stopped frequenting the southern and western parts of Svalbard as a consequence of the hunt, while they may still have summered in the northeastern parts where they were not observed until 1863.

In recent years walrus have not been observed at Moffen before about the middle of July. This relatively late appearance seems inconsistent with the theory that walrus winter on the nearby northern coasts of Nordaustlandet. Rather, it indicates that they migrate from wintering grounds farther away, for example Frans Josef Land.

Historically, Moffen has been an important haul-out site for walrus (e.g. Zorgdrager 1723). They occurred there in great numbers. For example in 1767 Dutch whalers killed about 2200 animals on the beaches of Moffen (Lindeman 1869). This island was apparently 'rediscovered' or 'recolonized' by walrus as a summer feedingarea and haul-out site about 1973. To enhance this development and reduce disturbance, Moffen was given status as a sanctuary on 3 June 1983 (T. Larsen pers. comm.). Hence, it is likely that walrus occurring in Svalbard are part of a population also occurring at Frans Josef Land, as also suggested by Norderhaug (1969).

Recent observations of walrus in Svalbard show an underrepresentation of females accompanied by newborn and one-year-old calves. Classification into the categories adult/subadult or male/ female may be difficult. However, the recognition of newborn or dependent calves is likely to be relatively easy. Therefore, the underrepresentation of dependent calves in the observations is likely to reflect the lack of this age-class in Svalbard.

Apparently, females with calves occurred more commonly in Svalbard. For example, Malmgren (1864) reported that his catch of walrus in Hinlopenstretet was composed exclusively of females with two- or three-year-old calves, although he also commented on the general absence of females with newborn calves in the Svalbard area. It is likely that females with newborn calves summer either at Frans Josef Land or further to the east. Bruce \& Clarke (1899) stated that very few bulls were found among the walrus during the summer near Cape Flora (Frans Josef Land); nearly all were females and most of them in July and August were attended by young. On the other hand, Tsalkin (1937) reported that the bulk of the animals at Frans Josef Land were largely males and that females and young were observed infrequently. However, Tsalkin's statement is somewhat contradicted by the fact that a fair proportion of the walrus catch in 1932 and 1933 at Frans Josef Land comprised females and young (Tsalkin, op. cit.).

Tsalkin (1937) noted that the number of walrus at Frans Josef Land changed from year to year. The varying numbers observed in Svalbard (e.g. the 1973 observation at Kvitøya by Benjaminsen et al. 1973) and at Frans Josef Land may indicate that walrus are not stationary in either area, and immigrate in varying numbers from year to year.

A connection between the walrus at Frans Josef Land and at Novaja Zemlja is indicated by Bychov (1975). According to Chapskii (1936), parts of the Kara Sea walrus population summered off northeastern Novaja Zemlja. The southern part of the Barents Sea is also considered to be the wintering ground of the Kara Sea walrus (Bel'kovich \& Khuzin 1960).

Despite complete protection of the walrus in Svalbard and the banning of commercial walrus hunts in the western sector of the Soviet Arctic (Bychov 1973), the walrus population(s) in these areas is still low. Bearing in mind that the true connection between walrus in Svalbard, Frans Josef Land, Novaja Zemlja, and in the Kara and Barents Seas is virtually undetermined, the estimates given here presumably give only an order of magnitude of the numbers of walrus. According to Yablokov (1972) the walrus had practically vanished from the Barents and Kara Seas. Lukin (1978) stated that the total number of walrus wintering in the southeastern Barents Sea appar- 
ently did not exceed 100-120 heads. Chapskii (1936) estimated the population in the Kara Sea to number a maximum of 1200 individuals during the 1930s.

The Yamal Peninsula 'stock' in the Kara Sea was estimated at 200-300 animals by Bel'kovich \& Khuzin (1960). A continued decrease of the walrus at Novaja Zemlja since 1941 when Chapskii (1941 fide Bel'kovich \& Khuzin 1960) estimated the total population frequenting this area at 2000-3000 animals was reported by Bel'kovich \& Khuzin (1960). According to Belobodorov \& Timoshenko (1974), about 200-250 walrus occurred at Novaja Zemlja in the late 1960s. Calculations of the numbers in the Novja Zemlja 'stock' gave an estimate of not more than 400 animals (Bychov 1975).

On 13 August 1979, 100-150 walrus were observed at Nortbruk Island (Frans Josef Land), where about 300 animals were seen in September. Apparently these groups were composed of adults and younger animals. This was the first sighting of walrus at Frans Josef Land for many years (Nazarenko 1980).

Except for five observations representing six animals (Appendix), all walrus observed at Svalbard were found in areas where the water depth is less than $100 \mathrm{~m}$. This is consistent with the fact that the walrus is a shallow-water bottom-feeder (e.g. Vibe 1950). Walrus food items were reported from several shallow-water localities in Svalbard and from the Frans Josef Land archipelago (Hägg 1905). Malmgren found parts of the bivalves Mya truncata and Hiatella byssifera (Saxicava rogusa, Sic!) in the stomachs of walrus in Hinlopenstretet. Observations obtained during the 1982 study (Table 2) indicate that the Murchisonfjorden area, Tusenøyane, and the northern coast of Nordaustlandet are walrus feeding grounds, and so presumably are Moffen, Storøya, and Kvitøya. The presence of extensive shallow-water areas with suitable walrus food in Svalbard indicates that availability of food is not an extrinsic factor limiting growth and distribution of the present walrus 'stock' in these areas.

\section{Conclusions}

About 100 walrus summer in the Svalbard area. The observation of at least 300 animals near Kvitøya in 1973 (Benjaminsen et al. 1973), however, shows that in some years the number may vary. It is thought that the wintering stock is in the low tens. It has still not been determined whether the walrus occurring in Svalbard, at Frans Josef Land, at Novaja Zemlja, and in the Barents and Kara Seas belong to one population or whether they occur in effectively isolated stocks.

The underrepresentation of observations of females with newborn in Svalbard indicates that the walrus occurring in this area belong to a population with a wider range. It is believed that polynyas occurring along the southern parts of Frans Josef Land are the wintering grounds for some of these walrus.

Recent observations from Svalbard indicate an increase in the number of walrus frequenting the archipelago during summer. Apparently, Svalbard is in the process of being 'recolonized' from the east, in particular by male walrus. As part of this process there has been an increased use of Moffen Island as a summer haul-out site.

\section{Recommendations}

In determining the sex and age composition and the total numbers of walrus summering in Svalbard it is recommended that synchronous aerial surveys be carried out in August at Moffen, in Murchisonfjorden, at Tusenøyane, along the northern coasts of Nordaustlandet, and at Storøya and Kvitøya. In determining the numbers in the wintering stock the same areas should be surveyed in March. It is also recommended that 'groundtruthing' data be obtained at Moffen in JuneSeptember. The feasibility of marking walrus at Moffen should be considered to determine sitefidelity and obtain an estimate of the number of walrus frequenting the Moffen area during summer.

Acknowledgements. - I am greatly indebted to the many people who through the course of the years have contributed information on walrus in Svalbard. I am particularly indebted to T. Larsen and F. Mehlum (Norwegian Polar Research Institute, Oslo) for their great help and encouragement during this study. I thank F. H. Fay (University of Alaska, Fairbanks), O. Lønø (Oslo), B. Gulliksen and T. Haug (Marine Biological Station, Troms $\emptyset$ ), and T. Martins (Sea Mammal Research Unit, Cambridge) for offering useful criticism of the first draft of this paper. I also wish to thank A. Børset (Sysselmannens Miljøvernskonsulent, Svalbard) for providing me with information on walrus in Svalbard. I thank the following colleagues for their inspiring company during the many cold hours we spent on the top-deck of 'Ymer' and 'Lance': R. Hansson, J. Thomassen, G. Granström, V. Ree, K. I. Ugland, K. Hjort, F. Mehlum, T. Larsen, H. Meltofte, B. Linnehol, R. Syvertsen, J. Hammar, O. N. Andersen, and I. Gjertz. 


\section{References}

Aabakken, R. 1976: Rapport fra naturvernskonsulenten hos Sysselmannen på Svalbard. Mimeo., 9 pp.

Allen, J. A. 1880: History of North American Pinnipeds. A Monograph of the Walrus, Sea Lions, Sea-bears and Seals of North America. Department of the Interior. U.S. Geological and Geographical Survey of the Territories. Miscellaneous Publications No. $12.785 \mathrm{pp}$.

Anonymous, 1966: Recent Norwegian laws relating to sealing. Polar Record 13, 209-211.

Bel'kovich, V. M. \& Khuzin, R. S. 1960: Atlanticheskii Morzh, Sberech' i Umnozhit' tsennoe zhivotnoe severa. Prirodo 1960(2), 67-69. [The Atlantic walrus: to save and increase a valuable animal of the North. Fish. Res. Board. Can. Transl. Ser. $345.4 \mathrm{pp}$ ].

Belobodorov, A. G. \& Timoshenko, I. K. 1974: Zashchitu atlantichesklogo morzha. [In defence of the Atlantic walrus.] Priroda, 1974, (3), 97-99. [Transl. Ser. Mar. Serv. Can. 3813 (1976): 7 pp]

Benjaminsen, T., Bergflødt, B. \& Øritsland, T. 1973: Selunders $\emptyset$ kelser i det nordlige Atlanterhav i 1973. (Seal investigations in the Northern Atlantic in 1973). Fiskets Gang 59, 853-863 [In Norwegian with an English summary].

Bruce, W. S. \& Clarke, W. E. 1899: The Mammalia and Birds of Franz Josef Land. Proceedings of the Royal Physical Society of Edinburgh. Session 1897-1898. Vol. 14, 78-112.

Bychov, V. A. 1973: Atlantic walrus, Odobenus rosmarus rosmarus L., 1758. Novaja Zemlja population. Paper 6, pp. 56-58 in: Seals IUCN Publications New Series, Supplementary Paper No. 39. 176 pp.

Bychov, V. A. 1975: Marine Mammals. pp. 27-38 in: Zhirnov, L. V., Vinokurov, A. A. \& Bychov, V. A. (eds.): Rare mammals, birds, and their protection in the U.S.S.R. Moscow Ministry of Agriculture.

Chapskii, K. K. 1936: The walrus of the Kara Sea. Results of the Investigation of the Life History, the Geographical Distribution and Stock of Walrus in the Kara Sea. Transactions of the Arctic Institute. Vol. 67, 1-124 [Leningrad 1936].

Chapskii, K. K. 1941: Morskie zveri sovetskoj Arktiki: Marine Mammals of the Soviet Arctic] Moskva/Leningrad, Izdatelstuo.

Hägg, R. 1905: Mollusca und Brachiopoda gesammelt von der Schwedischen Zoologischen Polarexpedition nach Spitzbergen, dem nordöstlichen Grønland und Jan Mayen im Jahre 1900. Archiv för Zoologi, uttg. af K. Sv. Vetensk. Akad. Vol. $2(2), 1-66$

Johansson, $\AA$. 1975: Valrossen har kommit tillbaka till Spetsbergen. Fauna Flora (Stockholm) 70(4), 143-144.

Lamont, J. 1876: Yachting in the Arctic Seas. Chatto and Windus, London.

Larsen, T. 1974: lakttagelser over dyrelivet pá Svalbard i 1972 (Observations of animal life in Svalbard in 1972). Nor. Polarinst Arbok 1972, 147-151.

Larsen, T. 1975: Iakttagelser over dyrelivet pá Svalbard i 1973 (Observations of animal life in Svalbard in 1973). Nor. Polarinst. Arbok 1973, 203-210.

Larsen T. 1976a: Observations of animal life in Svalbard 1974. Nor. Polarinst. Árbok 1974, 211-220.

Larsen, T. 1976b: Observations of animal life in Svalbard 1975. Nor. Polarinst. Arbok 1975, 179-186.

Larsen, T. 1977: Observations of animal life in Svalbard 1976. Nor. Polarinst. Árbok 1976, 319-326.

Larsen, T. 1978: Observations of animal life in Svalbard 1977. Nor. Polarinst Árbok 1977, 297-302.
Larsen, T. 1979: Observations of animal life in Svalbard 1978. Nor. Polarinst. Arbok 1978, 69-80.

Larsen, T. \& Norderhaug, M. 1974: Hvalrossen kommer tilbake til Svalbard. Norsk Natur 2, 44-47.

Lindeman, M. K. A. 1869: Die arktische Fisherei der deutschen Seestådte 1620-1868. Petermann Geogr. Mitteilungen Ergänzungsband 6, 1869-1871. Ergänzungsheft 26(6), 1869. $118 \mathrm{pp}$.

Lukin, L. R. 1978: O srokakh i rajonakh shchenki atlanticheskogo morzha (Time and regions of whelping of the Atlantic walrus). Ekologiya 5, 100-101 (Translated Northern Division, N. M. Knipovich. Polar Marine Fisheries Research Institute).

Lønø, O. 1970: The catch of walrus Odobenus rosmarus in the areas of Svalbard, Novaja Zemlja and Franz Josef Land. Nor. Polarinst. Arbok 1972, 199-212.

Malmgren, A. J. 1864: Beobachtungen und Anzeichnungen tber die Săugethierfauna Finmarkens und Spitsbergens. Archiv für Naturgeschichte, Berlin 30 Jahrgang 1. Band, 63-97.

Mansfield, A. W. 1958: The biology of the Atlantic walrus Odobenus rosmarus rosmarus (Linnaeus) in the eastern Canadian Arctic. Fish. Res. Board. Can., Manuscr. Rep. Ser. (Biol.) 653.146 pp.

Nazarenko, Yu. I. 1980: Morzhi na ostraovakh zemli Frantsa-Josifa (Walruses at the islands of Franz Josef Land). Priroda 1980 (1), 105-106

Norderhaug, M. 1969: Hvalrossens Odobenus rosmarus forekomst i Svalbard-området 1960-1967. Nor. Polarinst. Arbok 1967, 146-150.

Norderhaug, M. 1970a: Iakttagelser over dyrelivet på Svalbard i 1968. [Observations of animal life in Svalbard 1968]. Nor. Polarinst. Arbok 1968, 101-106.

Norderhaug, M. 1970b: Iakttagelser over dyrelivet på Svalbard i 1969. [Observations of animal life in Svalbard 1969]. Nor. Polarinst. Árbok 1969, 139-143.

Norderhaug, M. 1972: Iakttagelser over dyrelivet på Svalbard i 1970. [Observations of animal life in Svalbard 1970]. Nor. Polarinst. Arbok 1970, 264-270.

Norderhaug, M. 1973: Iakttagelser over dyrelivet på Svalbard i 1971. [Observations of animal life in Svalbard 1971]. Nor. Polarinst. Arbok 1971, 87-92.

Nyholm, E. S. 1975: Observations on the walrus Odobenus rosmarus in Spitsbergen in 1971-1972. Ann. Zool. Fennici 12 (3), 193-196.

Øritsland, T., 1973: Walrus in the Svalbard area. pp. 59-68 in: Seals. IUCN Publications New Series Supplementary Paper No. $39.176 \mathrm{pp}$.

Tollén. E. 1960: Däggdjur och fảglar på Nordostlandet, Spetsbergen. Fauna Flora (Stockholm), 79-96.

Tsalkin, V. I. 1937: Materials on the biology of the walrus of Franz Josef Land archipelago. Bull. Soc. Nat. Moscow., Sec. Biol. 46(1), 43-51.

Vibe. C. 1950: The Marine Mammals and the Marine Fauna in the Thule District (Northwest Greenland) with Observations on the Ice Conditions in 1939-1941. Meddelelser om Gronland 150(6). $115 \mathrm{pp}$.

Vinje, T. E. 1976: Sea ice conditions in the European sector of the marginal seas of the Arctic, 1966-1975. Nor. Polarinst. Arbok 1975, 163-174.

Vinje, T. E. 1982: Frequency distribution of sea ice in the Greenland and Barents Seas, 1971-1980. Nor. Polarinst. Arbok 1980, 57-61.

Yabiokov, A. V. 1972: A remarkable marine Mammal - the walrus. Nature (Moscow) 1972, 82-82. 
Zorgdrager, C. G. (1723) 1975: C. G. Zorgdragers alte und neue Grönländische Fischerei und Wallfischfang mit einer kurzen historischen Beschreibung von Grönland, Island, Spitsbergen, Nova Zembla, Jan Mayen Eiland, der Strasse Davis u.a. ausgefertiget durch Abraham Moubach. $\mathrm{Zu}$ ende ist allhier beigefüget eine summarische Nachricht von dem
Bakkelau-und Stockfischfang bein Terreneuf. Aus dem hollandischen übersezt, und mit accuraten Kupfern und LandCharten gesieret. Leipzig, bei Peter Conrad Monath 1723. Fotomekanischer Nachdruck Horst Hamecher, Kassel 1975. $482 \mathrm{pp}$, plus register. 


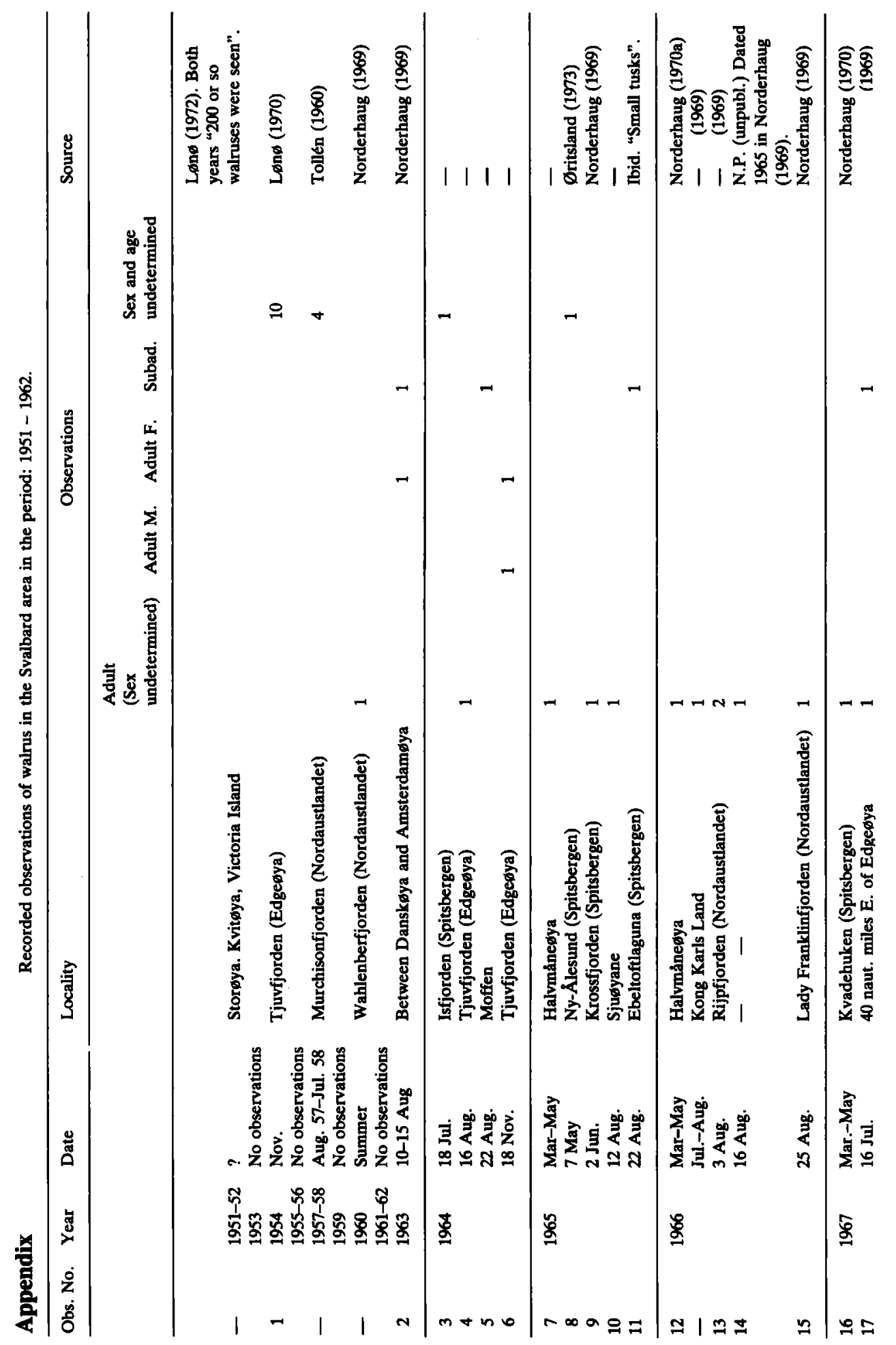



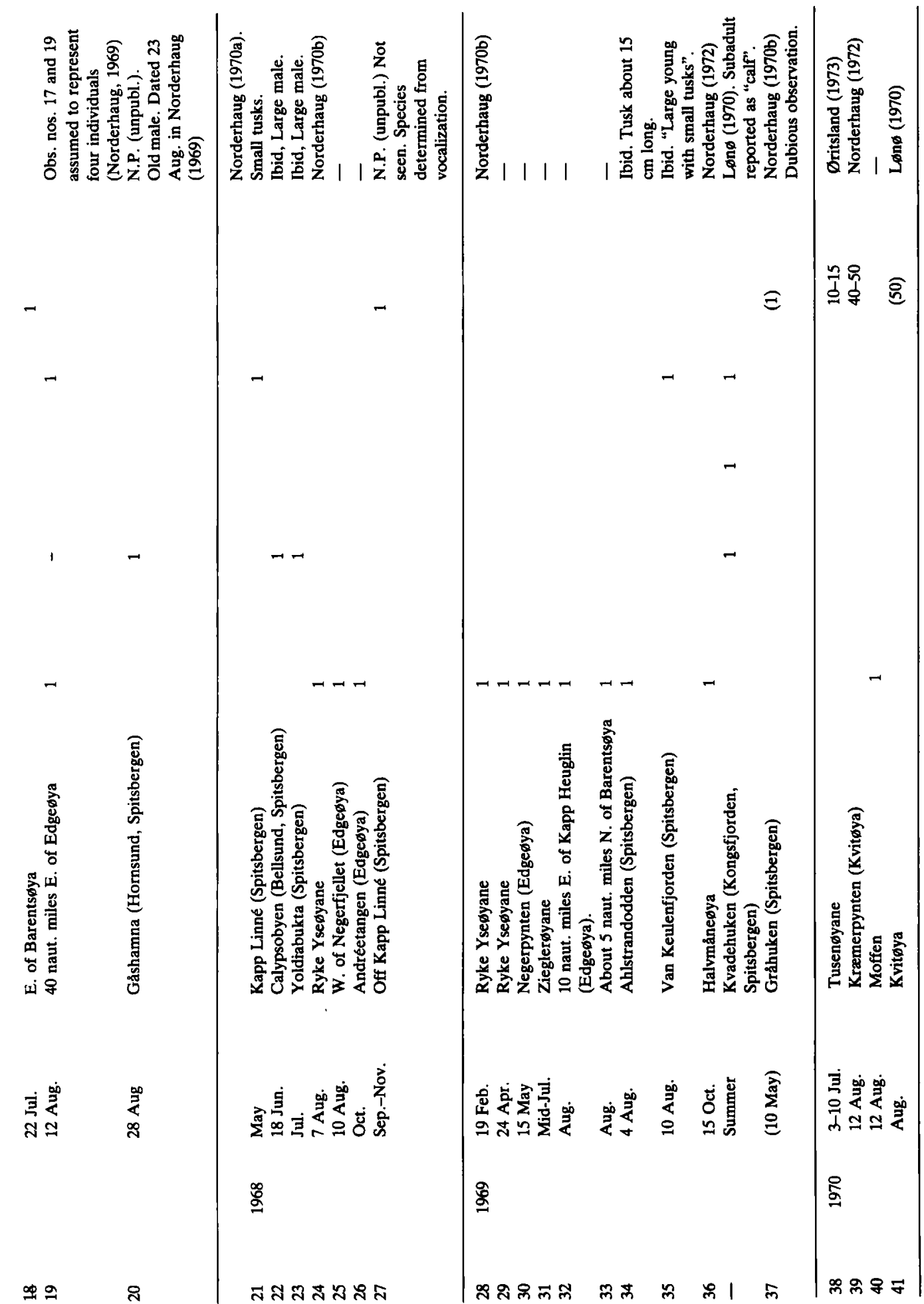


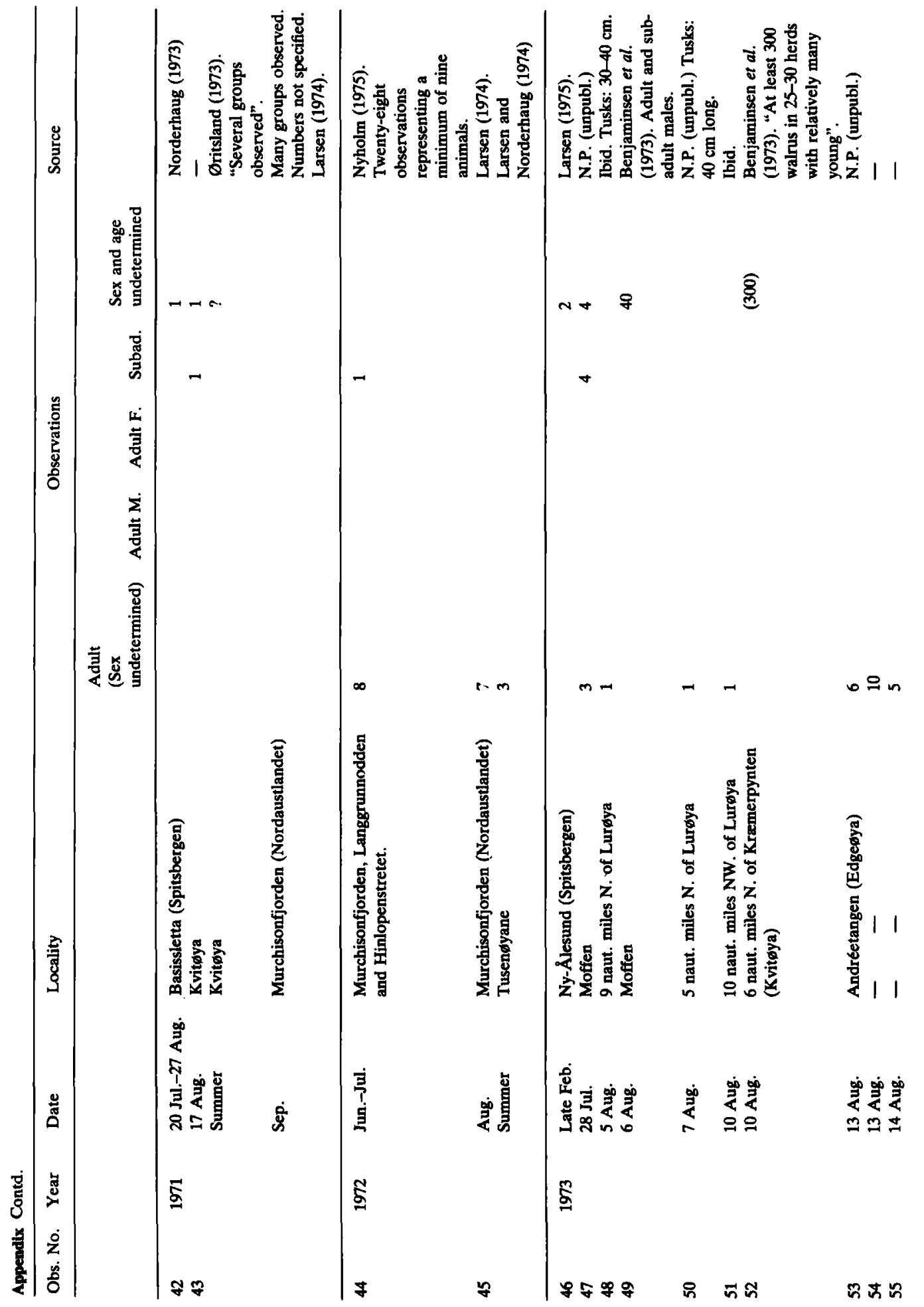




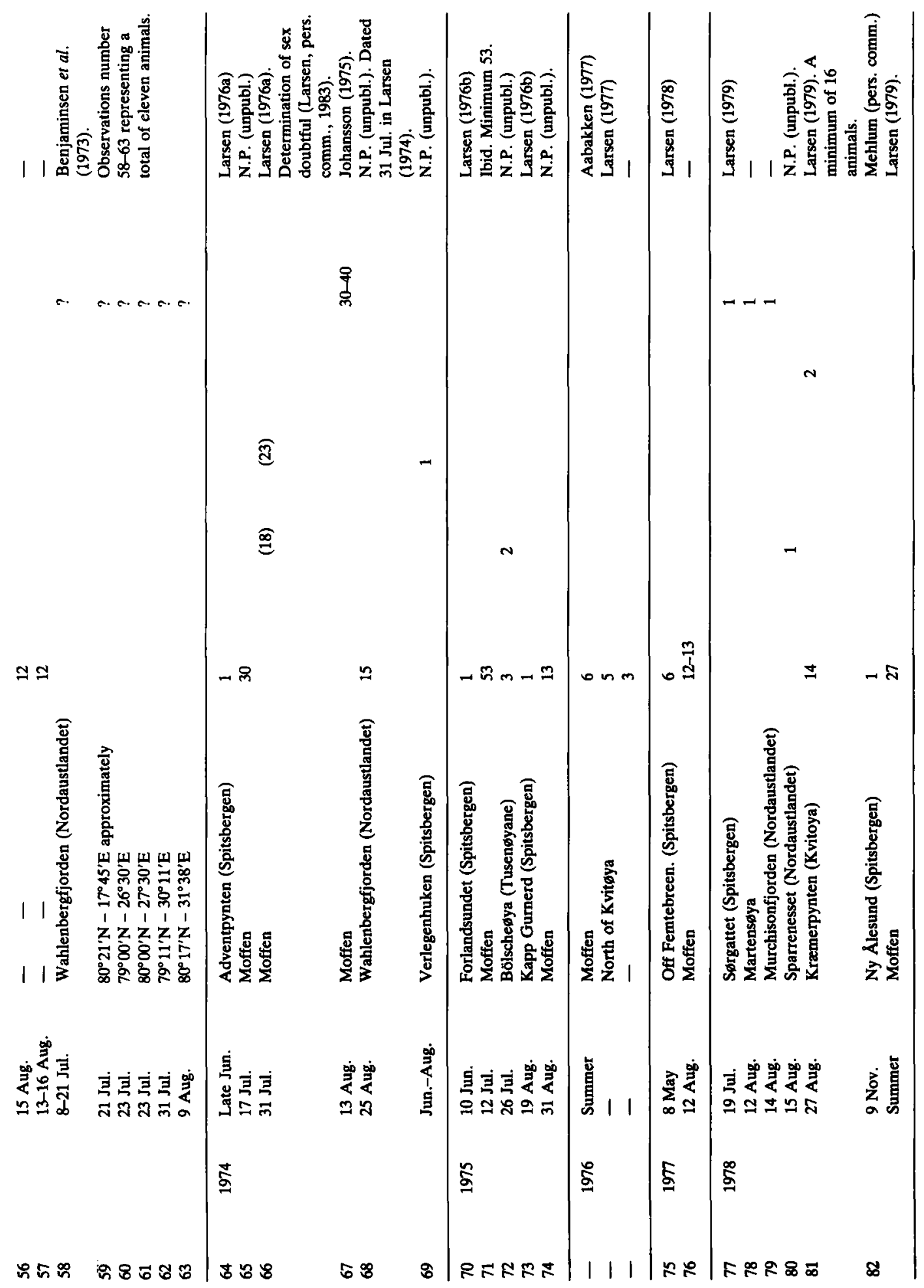




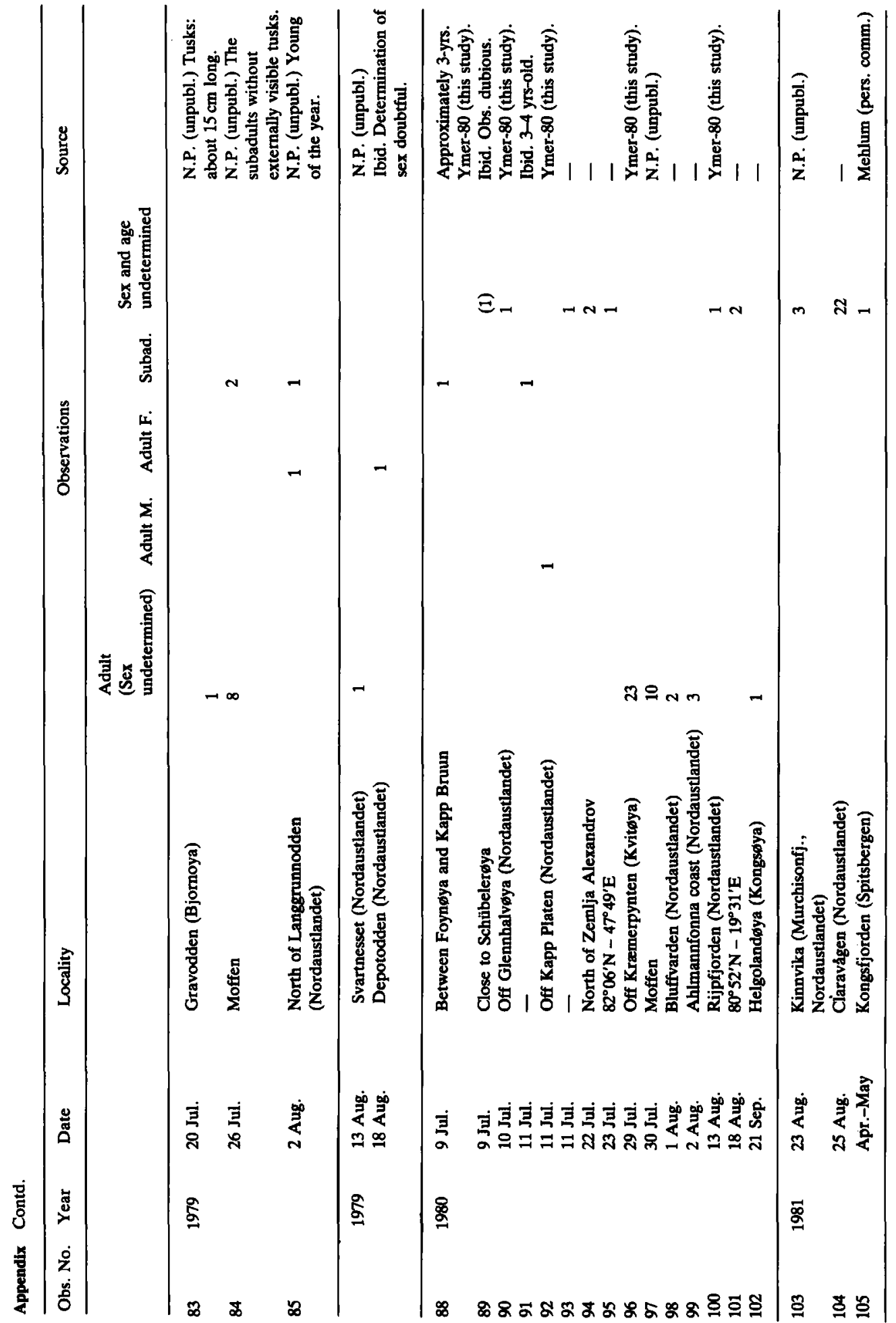




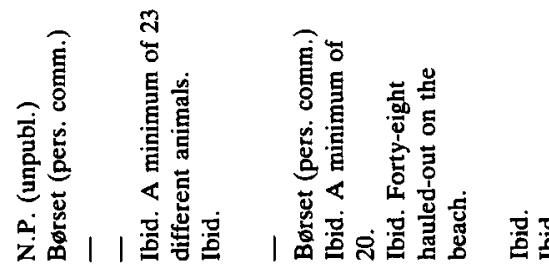

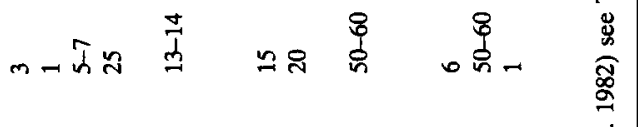

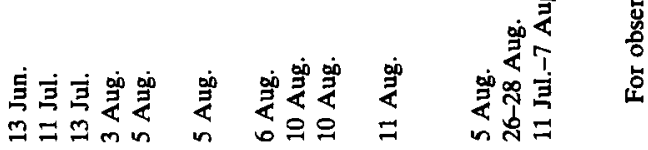

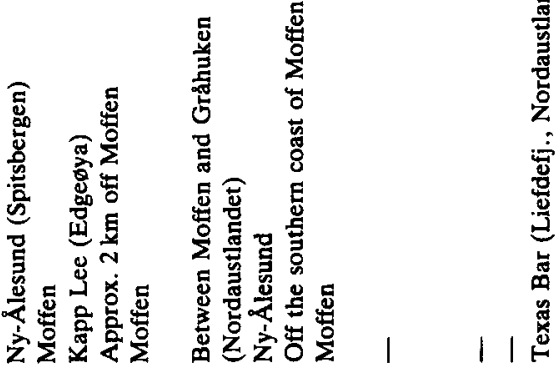

$\stackrel{2}{\approx}$

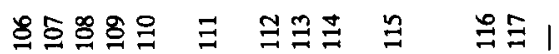

